
THE MOBILE STORY 



\section{THE MOBILE STORY \\ Narrative Practices with Locative Technologies}

Edited by Jason Farman

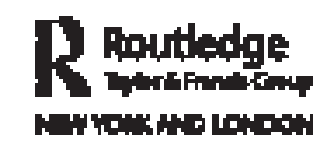


First published 2014

by Routledge

711 Third Avenue, New York, NY 10017

Simultaneously published in the UK

by Routledge

2 Park Square, Milton Park, Abingdon, Oxon OX14 4RN

Routledge is an imprint of the Taylor E Francis Group, an informa business

(C) 2014 Taylor \& Francis

The right of the editor to be identified as the author of the editorial material, and of the authors for their individual chapters, has been asserted in accordance with sections 77 and 78 of the Copyright, Designs and Patents Act 1988.

All rights reserved. No part of this book may be reprinted or reproduced or utilized in any form or by any electronic, mechanical, or other means, now known or hereafter invented, including photocopying and recording, or in any information storage or retrieval system, without permission in writing from the publishers.

Trademark Notice: Product or corporate names may be trademarks or registered trademarks, and are used only for identification and explanation without intent to infringe.

Library of Congress Cataloging-in-Publication Data

The mobile story : narrative practices with locative technologies / edited by Jason Farman.

pages $\mathrm{cm}$

Includes bibliographical references and index.

1. Mobile computing-Social aspects. 2. Digital media-

Social aspects. 3. Storytelling. 4. Spatial behavior. 5. Hypertext

literature. 6. Telecommunication-Social aspects. I. Farman, Jason.

HM851.M629 2013

302.23'1- dc23

2013005423

ISBN: 978-0-415-64148-7 (hbk)

ISBN: 978-0-203-08078-8 (ebk)

Typeset in Bembo

by Apex CoVantage, LLC 


\title{
LOCATION IS NOT COMPELLING (UNTIL IT IS HAUNTED)
}

\author{
Mark Sample
}

How do the examples in this chapter help us understand the practice of storytelling in the mobile media age?

Looking at the emerging practices of "checking in" to a location using locationbased social media, this chapter argues that such platforms for social interactivity tell us very little about our network, our interactions, and our places. Location is not compelling. To state it more accurately: your location is not compelling. While location may not be compelling, stories are, and this chapter explores various ways to "misuse" existing locative social networks for narrative purposes. Beginning with the thought that GPS receivers are made for storytelling (yet predominately offer only an impoverished notion of place), this chapter seeks to reconcile the poor connection between locational tools and narrative. The connection between these categories is explored by discussing a storytelling practice called "Haunts," which uses existing locative social media to tell stories.

\section{Keywords}

- Haunts: A game in which teams work to leave fragments of a narrative around various spaces using existing locative social media.

- Ubiquitous media: A postdesktop paradigm for computing, in which the technologies we interact with weave themselves into everyday life. These media are seemingly everywhere but often become so incorporated into our actions that we rarely notice them.

- Heterotopias: Drawn from the theories of Michel Foucault, heterotopias are a single "real" place that is layered with incompatible counter-sites. These counter-sites are juxtaposed against one another, often telling very different stories about the same location. 


\section{Introduction}

I am strangely drawn to the power of GPS, to the possibility of knowing my precise location on the face of the planet. This aspect of the Global Positioning System, of pinpointing myself on a map, has always been more fascinating to me than navigation or turn-by-turn directions. I don't want to know to where I'm going or how to get there. I want to know where I am. There's something magical, something mystical about seeing myself as a little pushpin in a map right there on the screen of my phone. I'm reminded of a scene in Don DeLillo's uncannily prescient White Noise, when the narrator Jack Gladney checks the balance of his bank account on an ATM. "The figure on the screen roughly corresponded to my independent estimate," Jack says with wonder. An "estimate," he continues, "feebly arrived at after long searches through documents, tormented arithmetic. Waves of relief and gratitude flowed over me.The system had blessed my life. I felt its support and approval."1 In the early days of GPS, I felt a similar sort of blessing when I saw my position on a map. Spiritual validation: the satellite gods in the sky have deemed me to be exactly where I think I am.

White Noise was published in 1985, which incidentally was the year that the tenth and final BLOCK-I GPS - in those days known as NAVSTAR - satellite was placed into orbit on an Atlas E/F rocket, launched from Vandenberg Air Force Base. Developed by Rockwell International in the 1970s, the BLOCK-I satellites were 1,700-pound proof-of-concept orbiters, designed to test the idea of a globalscale geographic positioning system. ${ }^{2}$ Such a system had been a dream of the U.S. military since the 1950s, when it became crucial for the Navy to know the precise locations of its Polaris missile submarines. ${ }^{3}$ While the Department of Defense built a system of low orbiting satellites called TRANSIT in the 1960s for this purpose, it was primitive compared to NAVSTAR; for example, TRANSIT offered only two-dimensional fixes (latitude and longitude) instead of three-dimensional fixes (which would also include elevation). Not only did NAVSTAR work, but the BLOCK-I satellites lasted far longer than their projected three-year lifespan. In 1989 the United States began updating the system with BLOCK-II satellites, and by 1995, modern GPS was fully operational, with twenty-four satellites orbiting the planet. For the first few years, only the U.S. military and other government entities had full access to GPS signals; the military intentionally reduced the system's accuracy for everyone else under a program called Selective Availability. ${ }^{4}$ On May 2, 2000, Selective Availability was shut down, and the system was entirely opened up for nonmilitary use. ${ }^{5}$

\section{Ubiquitous GPS}

GPS as we know it is less than two decades old. Yet consider this astonishing fact: by May 2012, nearly half of all American adults-46\% to be preciseowned a GPS-enabled smartphone, an incredible adoption rate for a technology that has only been available to civilians for twelve or so years. These smartphone 
owners use the GPS on their phones too. Almost three-quarters of them (74\%) access location-based information on their phones, such as directions or restaurant recommendations. ${ }^{6}$ GPS is so ubiquitous that it's difficult to imagine a world without it.

But of course, many of us can. Almost everyone born before 1985 has a GPS origin story, a narrative about their first experience with GPS, similar to the stories their parents or grandparents might tell about their first television set. My own is earlier than most, but later than some. In between the opening up of GPS in 2000 and the debut of YouTube five years later, I received my first GPS device. It was an all-black peripheral made by Magellan, roughly the size of a paperback book, and it snapped onto my silver Palm Tungsten T PDA. In hindsight, what I liked about this pairing is how explicitly peripheral GPS receivers used to be. Called the Magellan Companion, it was an add-on accessory, an afterthought even. The maps on this Palm-Magellan combo were crudely rendered, blocky vector graphics against a white background. Nevertheless, using this piggybacked GPS receiver was a powerful engagement with what Edward Soja calls a "secondspace perspective." While a firstspace perspective is rooted in the material world, the secondspace perspective is conceptual, a kind of a cognitive map, externalized in this case onto a GPS receiver screen. Unlike Jorge Luis Borges's map of the empire, there was no danger that this $320 \times 320$ pixelated map would ever replace the territory it represents. Yet at the time it was engrossing and immersive, perhaps precisely because it was confined to such a small space. It shrunk the whole world into the Palm in the palm of my hand. I vividly remember the day my Magellan GPS receiver arrived. It was May 2003. I was still a graduate student, and I was supposed to be working on my dissertation. Instead I was checking the progress of the package on the UPS website all day. In an ironic twist, UPS delivered it to the wrong address. When I saw it had been delivered, but not to me, I panicked. I called UPS, and because I called within minutes of the misdelivery, UPS was able to retrieve my package and get it to me that day. As soon as I had unboxed the device, I ran outside and stood in a wide open field, arms held high, waiting for my Palm to detect signals from space. That moment is when I first felt that validation, that approval that Jack Gladney felt. But mine was even more essential. The ATM simply told Gladney how much money he had. My GPS told me my worth. It told me my place in the universe.

A few years later I received as a gift a PDA with the GPS receiver built right in, an iQue 3600 made by Garmin. Hyperbolically named, the 360 degrees of a compass elevated by a power of ten, the iQue automatically switched to GPS mode when a small antenna was flipped up. In a matter of two years, GPS had gone from a clunky accessory for my PDA to a component integrated into the device-which, of course, I should add, itself was an accessory, something I carried along with my MP3 player and my cell phone. And now, a few years later, for many, if not most of us, GPS is a hidden part of that single accessory 
we never leave home without, that accessory so seemingly necessary that it's more of an appendage than an accessory. The phone. It's a prosthetic, not a peripheral.

The progression from an obviously external GPS receiver to an invisible element of the most take-it-for-granted device of the twenty-first century reminds me of something the science fiction author Bruce Sterling once wrote: that the difference between the technology of modernism and the technology of postmodernism is a matter of size and intimacy. The technology of modernism culminated in breathtakingly tall steel skyscrapers and gargantuan concrete dams, what David Nye calls the "technological sublime." The most advanced technologies today are the opposite-small and personal. The technology of postmodernism is technology that, as Sterling puts it, "sticks to the skin, responds to the touch." 9

Sterling wrote that in 1986.

Nearly thirty years later, and a decade into my own GPS narrative, I still feel a thrill when my location on Earth is validated by satellites in space. GPS is not merely for finding one's self on the map anymore, though. Nor is GPS limited to directions and wayfinding. Over the past few years, a number of location-aware mobile services - the most popular is Foursquare-have emerged. The focus of these social media services is "checking in" to venues and sharing those checkins with a circle of friends or, in some cases, strangers. Most of these mobile apps let you tag your check-in with a note or a photo, and some of them incorporate game-like elements, such as the coupons and badges Foursquare offers for repeated check-ins. I've experimented with most of these geosocial services, and I've reached a conclusion at odds with my own history with GPS.

\section{Location Is Not Compelling}

Location is not compelling. Or, perhaps, to state it more accurately: your location is not compelling. I still enjoy having my own location verified by satellites in the sky. But I'm too busy with my own life to care about your exact location. Especially when most of the people I know are either students or professors, and the only places they ever seem to check in to are coffee shops, classrooms, or bars.

Research suggests that I'm not alone in thinking that sharing one's location is not compelling. In November 2010, when interest in geosocial services had reached a fevered pitch and the field was crowded with many competing-and now defunct-services (Gowalla, Loopt, Brightkite, and MyTown among them), the Pew Research Center's Internet \& American Life Project found that only $4 \%$ of adults who were online used check-in services. That figure was actually a decrease from May 2010, when 5\% of online adults reported using check-in services. ${ }^{10}$ The numbers have grown steadily since 2010 , but users of geosocial services are still relatively rare. By May 2012, when 74\% of smartphone owners were regularly relying on the location services on their phones for directions or 
recommendations, the Pew Research Center found that only $18 \%$ of these smartphone owners checked in to locations or shared their locations. ${ }^{11}$

Why?

Pew doesn't say. But I'll restate my own theory: because your location is not compelling. Check-ins are not compelling. They offer an impoverished sense of place. Borrowing from Clifford Geertz, we might say that a check-in is a "thin" description of a place. Under the check-in model, every location becomes a point-of-sale and little else. Check in to a California Tortilla on Foursquare, and you earn free chips and salsa. But do you learn anything about the place itself? Do the friends with whom you've shared the check-in learn anything either? Your check-in, from their point of view, is simply an advertisement for California Tortilla. While I have, I admit, availed myself of Foursquare's special offers, they do nothing to sell me on the promise of geolocation. It is also true that some of the benefits of geolocation have been seized upon by museums and historians. For example, Foursquare and the History Channel have partnered up to provide historical tidbits if you check in near a historic locale. ${ }^{12}$ In practice this version of pop-up history is history "lite," lacking any kind of creative or pedagogical imagination, little different from a Fodor's guidebook. In general, check-ins are a consumerbased, trivial use of technology, and most smartphone owners recognize this.

The world is a rich and a complicated place, with layers of hidden experiences embedded in the most mundane of spaces, and these experiences do not deserve to be reduced to a badge on a screen. The social geographer E.V. Walter highlights what he calls the expressive intelligibility of places by noting that the ancient Greeks' oldest word for place was chora, which referred to the "spirit of a place." Chora is distinct from the other ancient Greek word for place, topos, which referred to the geographic location itself or the "objective features" of a place. Walter recalls that the opening chapter of Geographia, Ptolemy's second-century A.D. masterpiece, retains this distinction between chorography and geography. Ptolemy saw these two modes of mapping as separate disciplines. Geography, as Walter explains it, "pictorially represented the earth as a whole, describing its nature, position, and general features," while chorography "set off a part of the world, exhibiting it separately, representing exactly and in minute detail nearly everything contained within it." ${ }^{13}$ Maps over the centuries came to favor the former mode of representing the world, though this was not always the case, as expressive features - say a sea serpent or some other evocative beast-were once common features on classical and medieval maps.

\section{Beyond Location}

Like most modern maps, geosocial apps are bereft of any chorographic sensibility. They do not provoke the imagination or convey the spirit of a place. They do not express what folklorist Kent Ryden calls "the invisible landscape" of a place. By "invisible landscape," Ryden means the stories about a place that 
cannot be reduced to a Cartesian grid. The invisible landscape is comprised of lived history, both tangible and intangible. "While the modern map is a marvel of efficient geographical communication," Ryden writes, "in other important ways it does not tell us very much at all." ${ }^{14}$ Maps convey a limited range of geographic experiences: distance, elevation, vegetation, rivers, and buildings. But maps fail to convey the meaning of these geographic elements, how they impact both the broad history of a place and the daily life of the people who live there. Ryden's phrase "modern map" might easily be replaced by "modern app." Ryden calls for a reawakening of the discipline of chorography. "If geographers," Ryden observes, "make maps and formulate interpretations of the physical landscape, chorographers are mappers and interpreters of the invisible landscape." ${ }^{15}$ Location-aware apps could prove to be the means to create such maps of the invisible landscape. I have a vision of infusing geosocial applications with a sense of depth, with meaning that goes beyond the check-in. We ought to repurpose Foursquare and similar geolocative apps in order to foster critical and creative misuse of technology, and to encourage serious yet playful (or, playfully serious) chorographic thinking. Let's turn locative media from gimmicky entertainment coupon books and glorified historical guidebooks into platforms for renegotiating space and telling stories about places.

Many of the mobile apps themselves contain the raw material for such chorographic work. Mappers need only play with the way they use these apps. When I say “play," I have in mind the game designers Eric Zimmerman and Katie Salen's concept of play: "free movement within a more rigid structure." ${ }^{16}$ In the case of geolocation, the rigid structure comes from the core mechanics of the different geolocation apps: checking in and tagging specific places with tips or comments. What's supposed to happen is that users visit bars or restaurants and then post tips on the best drinks or bargains. But what can happen, given the free movement within this structure, is that users can define their own places and add tips that range from lewd to absurd. For example, within my dully named building at George Mason University, Robinson A, I've created my own space, The Office of Incandescent Light and Industrial Runoff. Likewise, when I'm home, I often check in to the Treehouse of Sighs. I have an actual tree house in my yard, but the Treehouse of Sighs is not that one. The Treehouse of Sighs exists only in my mind, part of the invisible landscape.

Not all geosocial services allow users to create new locations. Some, like Google Latitude, only allow users to check in to verified places. In this case, it can be just as evocative to tag existing venues with virtual graffiti, which you can use to create a counterfactual history of a place. Anyone who checks into the Starbucks on my campus can see my advice regarding the fireplace there ("The fireplace isn't real but if you close your eyes really tight and think about Bambi fleeing a forest fire you can almost smell smoke").Also on my campus I've uncovered the research library's powerful secret ("Probably the best place to read tacos on campus"). I've left surrealist epigrams in other public places, like the enigmatic 
tip in the claustrophobic Z terminal of Washington-Dulles International Airport ("The clocks in the walls of the hulls of the plane are bent, broken, and hard to wind").

All of this play has led me to consider teaching students to evaluate geosocial media by using geosocial media. My initial idea was to have students add new venues to Foursquare's database, with the stipulation that these new venues be Foucauldian "Other Spaces" ${ }^{17}$ — parking decks, overpasses, bus depots, and so on-that stand in sharp contrast to the officially sanctioned places on Foursquare (coffee shops, restaurants, bars, parks). One of the points I'd like to make is that much of our lives are actually spent in these nether-places that are neither here nor there. Tracking our movements in these unglamorous but not unimportant unplaces could be a revelation to my students. It might actually be one of the best uses of geolocation - to defamiliarize our daily surroundings.

But let's take this idea further. Why not combine the various elements of my playful approach to geosocial media: other spaces, other stories, an invisible landscape both written and excavated by visitors to those spaces? This is how my idea for an alternate reality game called Haunts developed. Haunts is part game, part story, a kind of game about stories.

\section{Haunts: Narrative Play as Creative Misuse}

HAUNT, v.- from the French hante-r (12 ${ }^{\text {th }}$ century), "of uncertain origin . . it is not clear whether the earliest sense in French and English was to practise habitually (an action, etc.) or to frequent habitually (a place)."

-Oxford English Dictionary, Second Edition ${ }^{18}$

The word "haunt," as its origins in French make clear, refers to both a practice and a place. No ghosts are necessary. Any living soul can haunt a place, making that place a haunt. The ghosts appear only when those living souls have departed, making a haunt haunted, a physical space permeated with spectral traces. In other words, a physical space written over with stories, a chorographic space.

Haunts is about the secret stories of spaces.

Haunts is about the production of what Foucault calls "heterotopias" — a single real place in which incompatible counter-sites are layered upon or juxtaposed against one another. ${ }^{19}$

The essence of Haunts is this: players (in my case, I imagine students) work in teams, visiting various public places and tagging them with fragments of a fictional story. This story explores the various "traumas" of a space. I'm using "trauma" in the most open-ended way possible here, in the same way that trauma itself is open - any open wound, any unassimilated experience. As a narrative framework, trauma is especially fitting for Haunts. Trauma is often connected to a place in a way that it is never quite connected to a time. ${ }^{20}$ Because trauma is enduring, what Cathy Caruth calls an "unclaimed experience," it is nearly timeless for the 
traumatized victim, but it is not placeless. ${ }^{21}$ Individual and collective traumas are part of nearly every inhabited place's invisible landscape. If chorography seeks to uncover the spirit of a place, Haunts seeks to imagine the unknown trauma witnessed by a place. Just as posttraumatic stress disorder (PTSD) is characterized by intrusive, repetitive memories, Haunts imagines the same traumatic kernel, being told again and again, from different points of view. ${ }^{22}$ Each team will work from an overarching traumatic narrative that they've created, but because the place-based tips are limited to text-message-sized bits, the story will emerge only in glimpses and traces, across a series of spaces. But emerge for whom? For the other teams, of course, but also for random strangers using the geosocial apps, who have no idea that they've stumbled upon a fictional world augmenting the real one-a fictional world haunting the real one.

Haunts is influenced by Augusto Boal's Theater of the Oppressed, particularly Boal's concept of "invisible theater," in which a scene is acted out-Boal uses the term "erupts" - in some public place, in front of people who are not spectators. As Boal puts it, "The people who witness the scene are those who are there by chance.... All the people who are near become involved in the eruption and the effects of it last long after the skit is ended." ${ }^{23}$ Haunts goes beyond invisible theater because the story or stories take place across a number of spaces. Most narratives do not require any kind of breadcrumb trail more complicated than sequential page numbers. In Haunts, however, players would need to create clues that act as what Marc Ruppel calls migratory cues-nudging participants from one locale to the next, from one medium to the next. ${ }^{24}$ These cues might be suggestive references left in a check-in note, or perhaps obliquely embedded in a photograph taken at the check-in point.

Another twist of Haunts subverts the tendency of geolocation apps to reward repeat visits to a single locale. As I've described, check in enough times at your coffee shop or Shell station with Foursquare and you become "mayor" of the place. Haunts disincentivizes multiple visits. Check in too many times at the same place and you become a "ghost." No longer among the living, you are stuck in a single place, barred from leaving tips anywhere else. Like a ghost, you haunt that space for the rest of the game. It's a fate players would probably want to avoid, yet players will nonetheless be compelled to revisit destinations, in order to fill in narrative gaps as either writers or readers.

The final twist of Haunts is that it does not rely on any single geosocial platform. Most geolocative apps have the same core functionality. This means players can use competing services, weaving parallel yet diverging stories across the same series of spaces. Each haunt hosts a number of haunts. The narrative and geographic path of a single team's story could alone be engaging enough to follow, but even more promising is a kind of cross-pollination between haunts, in which each team builds upon one or two shared narrative events, exquisite-corpse style. The trouble with building a haunt with multiple platforms, however, is that the platforms themselves are not necessarily reliable or long-lasting. The geosocial 
landscape has changed dramatically since I first conceived Haunts in 2010. Brightkite is no more; neither is Loopt. Gowalla shut down in 2012, after Facebook acquired the company in 2011. Facebook itself dialed back its aggressive push into check-ins, removing the "Places" button from its apps in 2011 as well. ${ }^{25}$ In some cases (for example, Loopt), users were provided a temporary way to download their check-in history as an XML file. Other services (for example, Gowalla) promised an "easy way to export your Passport data ... and your photos as well," but such capabilities never materialized. ${ }^{26}$ The result in the case of Gowalla is an entire history of geosocial activity that has become irretrievable, a literalization of the invisible landscape Haunts seeks to evoke. Given the inherent instability of social media, the history of geolocative apps oddly mirrors the kind of storytelling I had wanted Haunts to tell. The apps themselves become invisible, haunted places.

\section{Position/Navigation/Timing}

I have said that location is not compelling, but that stories about location are. There are in fact suggestive correspondences between GPS and stories, between location and storytelling. Nearly everyone knows that GPS stands for global positioning system, and many know it was originally developed by the military, but few know what government organization actually coordinates GPS. It is the cumbersomely named National Executive Committee on Space-Based PNT, established by a presidential directive in 2004 and made up of various cabinet secretaries, the Joint Chiefs of Staff, and NASA. ${ }^{27}$ And what does PNT stand for?

\section{Positioning \\ 2. Navigation \\ 3. Timing}

These sound to me a lot like storytelling terms. Isn't positioning analogous to perspective, the vantage point from which we witness a story? Navigation recalls the nontrivial choices readers make in what Espen Aarseth has coined "ergodic" narratives. ${ }^{28}$ And timing is the heartbeat of narrative-chronology, plot, the sequence of events unfolding across time.

PNT: positioning, navigation, timing.

GPS is made for storytelling. It simply hasn't been understood this way. Haunts - and other mobile media narratives discussed in this collection-attempt to shift the focus of location-aware platforms away from geography and into the expressive realm of chorography. Perhaps Haunts will only ever work as a conceptual game, a thought experiment, but I find its project compelling, and even necessary. The endeavor turns a consumer-based model of mobile computing into an authorship-based model. It is a uniquely collaborative activity, but also one that invites individual introspection. It imagines trauma as both private and public, deeply personal yet situated within shared semiotic domains. It operates at the 
intersection between game and story, between reading and writing, between the topos and choro. And it might finally make geolocation worth paying attention to.

\section{Notes}

1. Don DeLillo, White Noise (New York: Penguin, 1985), 46.

2. United States Naval Observatory, "Block I Satellite Information," ftp://tycho.usno. navy.mil/pub/gps/gpsb1.txt.

3. Norman Bonnor, "A Brief History of Global Navigation Satellite Systems," Journal of Navigation 65, no. 1 (January 2012): 3 .

4. Ibid., 1-5.

5. United States Naval Observatory, "GPS Constellation Status," ftp://tycho.usno.navy. $\mathrm{mil} / \mathrm{pub} / \mathrm{gps} / \mathrm{gpstd} . t \mathrm{txt}$.

6. Kathryn Zickurh, "Three-Quarters of Smartphone Owners Use Location-Based Services,” Pew Internet \& American Life Project, http://pewinternet.org/Reports/2012/ Location-based-services.aspx, 2.

7. Edward W. Soja, Thirdspace: Journeys to Los Angeles and Other Real-and-Imagined Places (Oxford:Wiley-Blackwell, 1996).

8. David E. Nye, American Technological Sublime (Cambridge, MA:The MIT Press, 1996).

9. Mirrorshades: The Cyberpunk Anthology, ed. Bruce Sterling (New York: Arbor House, 1986), xi.

10. Kathryn Zickurh and Aaron Smith, "4\% of Online Americans Use Location-Based Services," Pew Internet \& American Life Project, http://www.pewinternet.org/ / media//Files/Reports/2010/PIP-Location\%20based\%20services.pdf, 2.

11. Zickurh, Three-Quarters of Smartphone Owners, 2.

12. Jolie O'Dell,"History Channel Launches Foursquare Campaign and a New Badge,"Mashable, April 13, 2010, http://mashable.com/2010/04/13/history-channel-foursquare/.

13. E.V.Walter, Placeways: A Theory of the Human Environment (Chapel Hill, NC: University of North Carolina Press, 1988), 116-119.

14. Kent Ryden, Mapping the Invisible Landscape: Folklore, Writing, and the Sense of Place (Iowa City: University of Iowa Press, 1993), 20.

15. Ibid., 50 .

16. Katie Salen and Eric Zimmerman, Rules of Play: Game Design Fundamentals (Cambridge, MA:The MIT Press, 2004), 304.

17. Michel Foucault, "Of Other Spaces," trans. Jay Miskowiec, Diacritics 16, no. 1 (Spring 1986): 22-27.

18. "Haunt, v.," Oxford English Dictionary (Oxford: Oxford University Press, 1989), http:// www.oed.com/view/Entry/84641.

19. Foucault, "Of Other Spaces," 24.

20. Brian Croxall, "Comment on Haunts: Place, Play, and Trauma," SAMPLE REALITY, June 1, 2010, http://www.samplereality.com/2010/06/01/haunts-place-playand-trauma/\#comment-4540.

21. Cathy Caruth, "Unclaimed Experience: Trauma and the Possibility of History," Yale French Studies, no. 79 (1991): 181-192.

22. For more on PTSD, see Bessel A. Van der Kolk and Alexander C. McFarlane, "The Black Hole of Trauma," in Traumatic Stress: The Effects of Overwhelming Experience on Mind, Body, and Society, ed. Lars Weisaeth, Bessel A. van der Kolk, and Alexander C. McFarlane (New York: Guilford Press, 1996), 3-23. 
78 Mark Sample

23. Augusto Boal, "Theatre of the Oppressed," in The New Media Reader, ed. Noah Wardrip-Fruin and Nick Montfort (Cambridge, MA:The MIT Press, 2003), 347.

24. Marc Ruppel, “Learning to Speak Braille," Ph.D. qualifying exam paper (College Park: University of Maryland, 2005).

25. Leslie Horn, "Gowalla Shuts Down Following Facebook Acquisition," PCMag.com, March 12, 2012, http://www.pcmag.com/article2/0,2817,2401433,00.asp.

26. Josh Williams. "Gowalla Is Going to Facebook," Gowalla, December 5, 2011, http:// gowalla.tumblr.com/post/13782997303/gowalla-going-to-facebook.

27. See http://www.pnt.gov/.

28. Espen J. Aarseth, Cybertext: Perspectives on Ergodic Literature (Baltimore: Johns Hopkins University Press, 1997). 